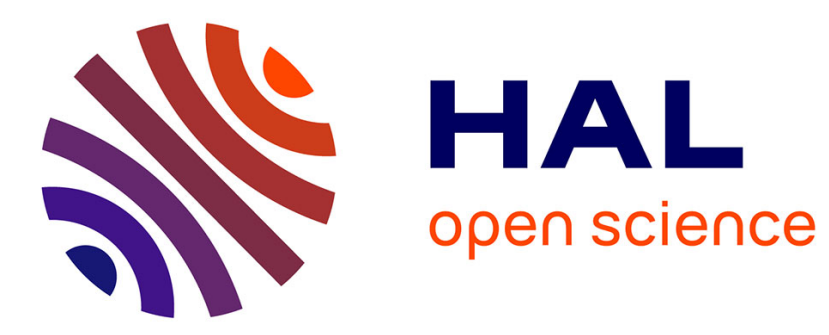

\title{
Safety and environmental control of industrial activities in France: A negotiated relationship
}

Valérie Sanseverino-Godfrin

\section{To cite this version:}

Valérie Sanseverino-Godfrin. Safety and environmental control of industrial activities in France: A negotiated relationship. 24th European Safety and Reliability Conference - ESREL 2014, Sep 2014, Wroclaw, Poland. pp.695-700 - ISBN 9781138026810. hal-01063678

\section{HAL Id: hal-01063678}

https://hal-mines-paristech.archives-ouvertes.fr/hal-01063678

Submitted on 29 Sep 2014

HAL is a multi-disciplinary open access archive for the deposit and dissemination of scientific research documents, whether they are published or not. The documents may come from teaching and research institutions in France or abroad, or from public or private research centers.
L'archive ouverte pluridisciplinaire HAL, est destinée au dépôt et à la diffusion de documents scientifiques de niveau recherche, publiés ou non, émanant des établissements d'enseignement et de recherche français ou étrangers, des laboratoires publics ou privés. 


\title{
Safety and environmental control of industrial activities in France: a negotiated relationship
}

\author{
Valérie Sanseverino-Godfrin \\ Center for research on Risks and Crises (CRC) \\ Mines-ParisTech, PSL Research University, Sophia-Antipolis, France
}

\begin{abstract}
Environmental regulation aims to ensure that industrial activities cause the least possible damage. In France, this includes checks of regulatory compliance by environmental inspectors. In cases of non- or partial compliance, the Environmental Code gives inspectors the power to impose sanctions: fines and/ or imprisonment. In theory, the relationship between the "inspector" and the "inspected" refers to a person with powers similar to those of the police who can punish all kinds of non-compliance, and another person considered to be an "offender". In reality, the objective of environmental inspectors is not to apply sanctions, but to promote economic development, by finding solutions that enable compliance with environment protection and safetv regulations.
\end{abstract}

\section{INTRODUCTION}

The inspection of industrial activities is a necessity. Mainly it is a question of sustainability - to protect the environment and natural resources from damage caused by these activities - but it also concerns the safety of people, evidenced by the many victims of major industrial accidents (Bhopal in India, Enscheda in the Netherlands, BP Texas City in the United States, and AZF in France, etc.). Environmental regulation aims to ensure that industrial activities cause the least possible damage. For instance, the operators of industrial plants in the European Union must comply with Seveso Directive regulations preventing pollution and risks. But it is not enough to provide regulations, it is also necessary to check that the regulations are correctly applied. In France, the risk of pollution caused by certain industrial plants (Installations Classées pour la Protection de l'Environnement) means that environmental inspectors (Inspection des installations classées) regulatory check their compliance with a special juridical framework. In cases of non- or partial compliance, the French Environmental Code gives inspectors the power to impose sanctions: fines and/ or imprisonment. In theory, the relationship between the "inspector" and the "inspected" (a private or public person, or a business) refers to a person with powers similar to those of the police who can punish all kinds of non-compliance, and another person considered to be an "offender". However, in reality the objective of environmental inspectors is not to apply sanctions, but to promote economic development, by finding solutions that enable compliance with environment protection and safety regulations.

This article shows that environmental inspectors negotiate their relationship with the entity they inspect, notably since the reform of the Environmental Code, which came into effect on 1 July 2013 and changed their role.

The article compares recent sociological studies of environmental inspectors, and the current state of regulations related to industrial activities in France. It gives also some examples from other countries, which are similar to the French situation. It addresses the question of whether safety imperatives can be negotiated.

The methodology consists of a bibliographic review of inspection and regulatory compliance, especially the sociological and juridical literature. It also examines the new control procedures contained in the Environmental Code (Articles L 170-1 and following). This review is complemented by a study of reports prepared by French inspection agencies (available on the internet), especially those of the agency in the Provence-Alpes-Cote d'Azur region. Finally, we study legal verdicts published on the official French website Légifrance, to identify information concerning prosecutions. This search used the keywords: inspection, compliance, violation, penalty, warning, fine and imprisonment for the period 2000-2013.

\section{INSPECTIONS - IN THEORY}

The objective of an inspection is that an industrial plant achieves regulatory compliance with environ- 
mental regulations. Checks are usually carried out by the national environmental agency, whose staff are experts in their sector: for example, Control of Major Accident Hazard (COMAH) regulations are enforced by national agencies such as the Environment Agency for England and Wales and the Scottish Environment Protection Agency; the Environmental Protection Agency in the USA; and the Regional Department for Environment, Planning and Housing (Direction Régionale de l'Environnement, de l'Aménagement et du Logement - DREAL) in France.

DREAL comes under the authority of the local representative of the State (the Préfet), and is the competent authority in decisions concerning industrial plants (notably permits and administrative sanctions). The agency's inspectors are engineers, who have both a scientific and technical background and very good knowledge of the French environmental legal framework.

The procedure for inspections and the powers of inspectors are detailed in the Environmental Code, supplemented by directives from the Department of Ecology. The inspection procedure has changed: first in 2006 and then on 1 July 2013, which introduced a new mode of inspection, based more on transparency and negotiation (see below).

The inspection is led by environmental inspectors and takes place at several key moments in the industrial plant's history: before activity begins (through the assessment of the project proposal put forward by the future operator), during active operations, and when activity ends and the plant is closed down. At each of these times, the objective is to check that the plant complies with regulations and does not cause disturbance (noise, smell, etc.) or increase risk to the neighbourhood. The most interesting period is when the plant's activities may cause several types of damage; this is the most important inspection carried out by inspectors and the one we focus on in our study.

Generally, environmental legislation gives inspectors special powers to check regulatory compliance: they can enter an industrial site, grant or withdraw permits, enforce standards and if necessary, prosecute the operator of a non-compliant plant (Fineman 2000). There is a graduated scale of threats and sanctions, ranging from financial penalty notices, compliance notices and restoration notices to criminal charges, etc. In France, inspectors are sworn officers and this status gives them certain powers. To obstruct the work of an inspector is an offense, punishable by a fine $(€ 150,000)$ and imprisonment (six months). To check regulatory compliance, inspectors may enter the plant at any time. The visit can be requested or unannounced. Most of the unannounced visits are due to complaints from neighbourhood residents. Inspectors can access any documents concerning the plant. They can also ask an external expert for their advice on the level of pollution or risks, which must be paid for by the plant's operator, if they consider the documentation to be insufficient or incomplete.

After an inspection, the inspector prepares a report (the lettre de conclusion), in which all the examples of non-compliance that have been observed are recorded. This report forms the basis for a prosecution in cases of non-compliance or failure to hold a permit. Before beginning a prosecution, the inspector can ask the Préfet to send a formal notice to the operator, which gives them time to rectify any deficiencies.

In principle, every case of non-compliance can be prosecuted, either once the notice's deadline has expired or, in serious cases immediately following the visit. Two types of sanctions can be applied: administrative and/ or penal. Administrative sanctions are applied if the plant remains non-compliant after the notice's deadline has expired. The objective is to make the plant compliant. To that end, the Préfet can order that the sums needed to pay for the necessary works be deposited (the amount depends on the cost of the work to be carried out to achieve compliance); have the work done at the operator's expense; or suspend the plants activity until it is compliant.

Depending on the offenses committed, criminal sanctions can be applied to the operator. They can be fined for non-compliance with the applicable legislation or non-compliance with the formal notice (up to $€ 100,000$ and two years of imprisonment). If the reason for the non-compliance creates serious damage to the environment, or is a risk to health or safety, the sanction may be a $€ 75,000$ fine and a year of imprisonment. The operator can also be issued with a penalty (maximum $€ 3000$ per day) until the plant is compliant.

We saw earlier that in France there is a special environmental inspection agency that is dedicated to monitoring regulatory compliance. In theory, a prosecution can be launched each time an inspector notes a case of non-compliance.

However, does this theoretical scheme correspond to reality? Several sociological studies on the subject suggest that there are differences between what an inspection is supposed to be and what it really is.

\section{INSPECTIONS - IN PRACTICE}

First of all, it is important to note that the overall number of inspectors is not enough to monitor all industrial plants. No government has sufficient resources to check regulatory compliance in each in- 
dustrial plant and to prosecute every failure (Zaelke \& Higdon 2006). The response to this situation is for environmental agencies to target their activities on those industrial plants that can cause serious pollution and damage to people and the environment, and those with the worst compliance records (Pedersen 2013).

In France, for example, there are about 500, 000 Classified Installations (Installations Classées), but only 1, 250 full-time inspectors (as of 31 December 2012). It is clear that it is impossible to check the regulatory compliance of every industrial plant. For this reason, the plants to be checked are prioritized. The Department of Ecology provided a modernized inspection program for 2004-2007 and a Strategic Inspection Program for 2008-2012. These two programs outline the methodology to be used in the inspection, the organization of inspectors, information and training. Based on these programs, each year the Department of Ecology decides actions and inspection priorities. One of these priorities is to check the regulatory compliance of the most dangerous or polluting industrial plants.

In the United Kingdom, similar priorities are defined: the "risk based approach" reduces the administrative burden by organizing the work of national agencies, especially the Environment Agency. It focuses on major technological and emergent risks (Galland 2008). The same observation can be made in Belgium: a natural response to the shortage of resources is targeting, with inspection focused on those plants that are suspected to be non-compliant with environmental regulations and those that are the more dangerous or polluting (Rousseau 2007).

This first observation shows that, due to the lack of inspectors, checks of regulatory compliance cannot be as rigorous as they should be according to the legislation. Moreover, an indirect consequence of the lack of inspectors is to encourage a culture of "making arrangements": the inspector has no choice but to trust the operator to be compliant, as there are few ways to impose the regulations as they are prescribed in the legislation. This is a move away from command and control methods towards a self-regulatory approach (Pedersen 2013).

The approach to inspections is important as it determines how regulatory compliance is handled. French regulations concerning inspections take a "safety case" approach (Hale et al. 2002), which means that risk prevention is the responsibility of the operator of an industrial plant: they have to prove that they have identified and assessed the risks, and adopted appropriate prevention measures. In brief, they have to prove that the plant is safe for people and the environment. In this context, the plant, especially in large industrial groups, is a "self-regulated organization", to which officials can impose sanctions if self-regulation is insufficient (Dupré et al. 2009).

Furthermore, the Department of Ecology has directed inspectors to be more tolerant and promote industrial development. In 1995, a memo from the Department received by environmental inspectors confirmed this position: "It is clear that environmental inspectors must first establish a dialogue with the operators of inspected plants. It is not possible to prosecute each case of non-compliance" (Bonnaud 2002). Sometimes, inspectors have a dual role: to check regulatory compliance and also to advise the operator. This is the consequence of their specific technical knowledge, which can be used both to check regulatory compliance and to support prevention initiatives taken by operators (Strasser 1996).

This flexibility has an impact on the relationship between the "inspector" and the "inspected": inspectors are free to build a cooperative relationship with the inspected, and there is room for compromise (Ayres \& Braithwaite 1991). Consequently, the regulatory compliance check is more based on negotiation. Etymologically, the Latin word "negotiation" means "trade or commerce". Specifically, it describes action to deal with an issue, the award of a contract and, by extension, various preliminary operations that are carried out in order to reach agreement. It also refers to discussions held before a contract is agreed or discussions concerning the settlement of a dispute (Cornu 2010).

In theory, there is no scope for negotiation in an administrative procedure that involves the inspection of an industrial plant, which may potentially lead to a prosecution in cases of non-compliance. However, sociological studies of regulatory compliance checks at industrial plants show that environmental inspectors negotiate their relationship with the entity they inspect. What is very interesting is that this conclusion is found not only in many French studies, but also in other countries (Hawkins 1984, Olsen 1992, Porter \& Van der Linde 1995, Lowe et al. 1997, Smith 1997, Fineman 1998, 2000). In general, as White observes, "the mandate of most environmental agencies is not only to enforce compliance through use of criminal prosecutions, but to forge strategic alliances and working partnerships with industries, local governments and communities in support of environmental objectives" (White 2010). In the United Kingdom, maintaining a collaborative/ negotiative relationship and a constructive dialogue 
with industries is crucial. Inspectors consider that without negotiation, the exercise becomes confrontational and while standards can be imposed, it is not sure they will be met (Fineman 2000).

In France, the sociologist Lascoumes carried out several surveys in the early 1990s of environmental public policies and particularly environmental inspections. From his point of view, the purpose of environmental policies is not to protect nature (a sacrosanct value based on indisputable standards), as this would result in a prosecution each time there is environmental damage. Instead, his study of policies showed that they are more like strategic compromises between conflicting interests (environmental protection, the development of the industrial economy, urban planning, etc.) than real protection measures. Policies are more concerned with the modes of the relationship between different stakeholders, than the results to be achieved. In short, environmental policy is not a simple protection policy, but an organizational policy in which the purpose is to establish procedures for resolving problems. In this context, the main action principle for environmental inspectors is the regularization of non-compliant industrial plants. This regularization is not based on prosecutions, but on negotiation. Of course, the end goal is always compliance by industrial plants with the legal requirements. However, there are many ways to achieve this goal: visits to plants, emails, telephone calls, meetings, formal notices; prosecution is the ultimate action, which only taken when all other procedures have failed (Lascoumes 1994).

"Speak softly and carry a big stick" may be said to summarize the environmental inspector's position, without forgetting that the big stick can and will be used (White 2010). This shows that inspectors have an ambivalent role: "enforcer-as-helper" and "prosecutor-as-advisor" (Fineman 2000). With respect to sanctions, "prosecution ought to be an equal partner in the enforcement tool box" (White 2010): sanctions are necessary for the threat to be credible and to compel regulatory compliance (Zaelke \& Higdon 2006). However, above all sanctions are an appropriate response to a particular set of circumstances (White 2010): this flexibility allows the inspector to tailor their response to the particular and distinct situation of each offender (Pedersen 2013). As Eckert (2004) notes in the case of Canadian and American inspectors, it is common for them to "respond to a detected violation by issuing a warning rather than prosecuting the violator". Eckert also noted that in cases of the inspection of petroleum storage facilities, the response to most violations has been a warn- ing, with only a small number of prosecutions or fines. In this context, prosecution may be considered as a "poisoned chalice", which is unavoidable (Fineman 2000). However, the decision to prosecute depends on the size of the company, its previous performance and compliance record, the intent of the operator, and their degree of courtesy and respect for the inspector (Fineman 2000). Finally, prosecution remains a necessary last resort in the most serious cases (Pedersen 2013).

\section{CONFIRMATION OF THE NEGOTIATION: THE FRENCH INSPECTION PROCEDURE}

In French judicial procedures, the defendant's rights are based on the adversarial principle (the principe $d u$ contradictoire), which means that both parties involved in a trial knows the arguments of their opponent.

In the context of the inspection of industrial plants, for many years administrative procedures did not provide any opportunity for the operator to be informed about developments and to present their own arguments. Prior to 2006, and the entry into law of the adversarial principle, the visit report was prepared by the inspector, working alone in their office. The plant's operator had no opportunity to make comments or to give their point of view. Moreover, the inspector was able to add new elements, which were not discussed during the visit. The time between the visit and the preparation of their conclusions was not clarified. This meant that in the time that elapsed between non-compliance being noted in the inspection and the formal notice sent by the Pré$f e t$, the operator was completely unaware of the subsequent procedures and administrative assessment of their case.

Little by little, the adversarial principle found in judicial procedures has influenced administrative procedures. In the following, we show that this principle forms the basis for a negotiation between the inspector and the operator of an industrial plant.

The French law that established citizens' rights in their dealings with the administration (12 April 2000) was the first to establish the principle of negotiation, by providing for "prior consultation" with the person who was the subject of a decision taken by an administrative authority; in this case the operator of the industrial plant.

At that time, the multiannual French environmental inspection program (2004-2007) had four main 
objectives. Two of them demonstrate the application of the adversarial principle: to increase the transparency of the actions of the inspector and to improve the coherency of all decisions taken on French territory. To achieve these objectives, the program provided easy access to information concerning the release of polluting materials, actions taken by the inspector to reduce industrial pollution and risks, and the results of the inspection, notably through the diffusion of information on the internet. This program has increased the visibility of inspection procedures and has allowed operators to be better informed of the procedures to be followed and how inspectors check industrial plants.

The Strategic Inspection Plan (2008-2012) confirmed the right of the general public to have access to documents related to industrial plant regulation, especially those concerning the inspection visit. The 2006 modification to Article L 514-5 of the Environmental Code officially gives the operator the right to be informed of any follow-up subsequent to checks by the environmental inspector. The 2013 reform of environmental inspection confirmed this trend. Consequently, henceforth the adversarial principle is applied in post-visit procedures and before a formal notice is issued.

Transparency and the adversarial principle lead to the institutionalization of negotiations, both immediately following an inspection, and ex post, during prosecution procedures. Inspectors no longer prepare their visit report immediately after the inspection. First, they prepare a list of issues to be addressed or observations. This is written on-site, immediately following the visit, during a debriefing meeting. The document is signed by the inspectors and the plant's operator. The operator can add their own observations and comments concerning the list, by mail or email, within three weeks of the visit. During this time they are expected to rectify any deficiencies.

This shows that the adversarial principle forms the basis for the procedure; the preparation of the list is the starting point for negotiations between inspectors and operators.

We have surveyed some of these lists, prepared by the environmental inspection agency in the Provence-Alpes-Côte d'Azur Region (in the south of France), which are available on the agency's website. This study shows that inspectors do not systematically demand compliance with the legislation. Most of the time, they indicate the issues that must be addressed within a certain timescale (usually three weeks). After the three-week deadline, the inspector updates the list with the following infor- mation: either the plant is compliant, or a formal notice is needed, or additional environmental measures are necessary. Next, they prepare their report (the lettre de conclusion), which summarizes the visit, the actions that were taken within the three weeks, or those which are planned and the time allowed to apply them. The same document also records any cases of previous non-compliance, which makes it possible to compare situations and see if the operator is making an effort to be compliant. The lettre de conclusion is send to the operator and can form the basis for a future formal notice.

This shows that the first part of the inspection procedure is based on negotiation; the objective is not to prosecute, but rather to find pragmatic solutions that address any deficiencies.

What happens in the case of non-compliance within the time indicated in the lettre de conclusion? The inspector, via the Préfet, can send a formal notice to the operator. In this notice, the Préfet reiterates the deficiencies that were found and gives a deadline for the operator to address them. According to a circular from the Department of Ecology (18 June 1998), this is a final warning and the deadline cannot exceed three months, except in special circumstances. However, in practice, this deadline is not always met. A study of court decisions shows that in some cases, a new deadline can be applied, notably when the plant is still non-compliant when the initial deadline expires. Moreover, several further deadlines can be applied, up to a period of two years (Baucomont \& Gousset 1994)!

The second part of the inspection procedure is also based on negotiation, and allows the operator more time to make the plant compliant, beyond the deadline indicated in the legislation.

Since the 2013 reform to the Environmental Code, a new form of sanction has been introduced: "penal transaction". Before prosecution, and as a replacement to it, the Préfet can agree transaction with the operator, depending on the circumstances and the seriousness of the offense, the nature of the operator and its resources. In this case, the Préfet and the operator discuss the amount of the transactional fine and the operator's responsibilities; the idea is to both punish the operator and pay for any damages. The amount is limited to a third of the initial fine.

The introduction of penal transaction is final confirmation that the objectives of environmental policies are not to issue sanctions in cases of noncompliance, but to try to reconcile different interests, especially economic. With this kind of sanction 
available, public authorities may become less and less strict.

\section{CONCLUSION}

This study shows that the control of industrial plants is based on a negotiation between environmental inspectors and the operator. The negotiation demonstrates the real objective of environmental inspection: to try to reconcile conflicting interests and to protect the environment to the greatest extent possible without hindering the development of industrial activities. This leads to a compromise: the objective of control is not to prosecute but to find solutions that lead to compliance. The recent reform of the Environmental Code formalized the negotiation and the concept of the inspection.

What will be interesting in future work will be to examine the limit(s) of this concept of negotiationbased inspection. Are inspectors open to negotiation on any topics concerning the environment, including issues that relate to personal safety? How far can deadlines for compliance be extended? Are there some cases of non-compliance that do not need to be prosecuted? What criteria should inspectors use to determine which cases of non-compliance should be prosecuted and those which should not?

In 1994, Pierre Lascoumes was doubtful about the limits of this kind of arrangement. Are repeated promises of compliance that are indefinitely postponed really tenable?

The answer has recently been given by the French administrative court, in the case of the AZF accident (Cour Administrative d'Appel de Bordeaux, January 24, 2013, $\mathrm{n}^{\circ}$ 10BX02880, 10BX02881). The question revolved around whether or not environmental inspectors could be held responsible for the explosion of the industrial plant. Could it be argued that the inspection had failed and that this failure was one of the elements that contributed to the explosion? For the judges, the answer was "yes". They noted that the operator had committed numerous lapses in the management of the plant, which could be considered to be negligent; however, they pointed out that the inspection agency also made numerous mistakes. The plant was inspected eleven times between March 1995 and May 2001, without any formal notice being sent to the operator about poor management. It appears that the building where the explosion happened had never been inspected. The operator was never prosecuted, despite obvious and persistent failures. The judges noted that the negli- gence of the inspection agency was particularly serious, as the plant was located in an urban area, which should have justified harsh measures being taken against the operator. Consequently, the French State, because of the mistakes of the environmental inspection agency, was considered as responsible of a part of the accident.

The inspection of industrial plants may be based on negotiation, but the courts remind us that the application of environmental rules can only be negotiated up to a certain limit; and this limit is reached when safety is affected.

\section{REFERENCES}

Ayres, I. \& Braithwaite, J. 1991. Tripartism: regulatory capture and empowerment. Law and social enquiry 16(3): 435-496

Baucomont, M. \& Gousset, P. 1994. Traité de droit des installations classées. Paris: Technique \& Documentation, Lavoisier.

Bonnaud, L. 2002. Experts et contrôleurs d'État: les inspecteurs des installations classées de 1810 à nos jours (thesis). Cachan: École Normale Supérieure de Cachan.

Cornu, G. 2010. Vocabulaire juridique. Paris: Quadrige, PUF, 8 th ed., 5 th print.

Dupré, M. Etienne, J. \& Le Coze, J.-C. 2009. L'interaction régulateur/régulé : considérations à partir du cas d'une entreprise Seveso II seuil haut. Annales des Mines, Gérer et comprendre, $\mathrm{n}^{\circ}$ 97: 16-27.

Eckert, H. 2004. Inspections, warnings, and compliance: the case of petroleum storage regulation. Journal of Environmental Economics and Management 47: 232-259.

Fineman, S. 1998. Street level bureaucrats and the social construction of environmental control. Organization Studies 19(6): 953-974.

Fineman, S. 2000. Enforcing the environment: regulatory realities. Business Strategy and the Environment Bus. Strat. Env. 9: 62-72.

Galland, J.-P. 2008. La prévention des risques technologiques et professionnels en France et en Grande-Bretagne, des années 1970 à nos jours. Revue française des affaires sociales 2008/2, n' 2-3: 301-321.

Hale, A. Goossens, L. \& Van de Poel, I. 2002. Oil and Gas Industry Regulation: from detailed technical inspection to assessment of safety management, in Changing regulation: controlling risks in society, ed. B. Kirwan, A. Hale, A. Hopkins, 79-106, Oxford: Pergamon.

Hawkins, K. 1984. Environment and enforcement: regulation and the social definition of pollution. Oxford University Press: Oxford.

Lascoumes, P. 1994. L'éco-pouvoir. Environnements et politiques. Paris: La Découverte.

Lowe, P. Clark, J. Seymour, S. \& Ward, N. 1997. Moralizing the environment. UCL Press: London

Olsen, P.B. 1992. Six cultures of regulation. Institute of Industrial Research and Social Development: Copenhagen Business School.

Pedersen, O. W. 2013. Environmental enforcement undertaking and possible implications: responsive, smarter or rent seeking? The modern law review, 76(2) MLR: 319-345.

Porter, M. \& Van der Linde, C. 1995. Green and competitive. Harvard Business Review September-October: 120-134.

Rousseau, S. 2007. Timing of environmental inspections: survival of the compliant. J. Regul.Econ. 32: 17-36 
Smith, A. 1997. Integrated pollution control. Ashgate: Aldershot

Strasser, K. A. 1996. Promoting pollution prevention and environmental technology in the United States traditional regulatory system. Tilburg Law Review, Vol 5, Issue 3:183-202.

White, R. 2010. Prosecution and sentencing in relation to environmental crime: Recent socio-legal developments. Crime Law Soc Change, 53: 365-381.

Zaelke, D. \& Higdon, T. 2006. The role of compliance in the rule of law, good governance and sustainable development. JFFP, 5/2006: 376-384. 